\title{
Diversity and Distribution of Biosurfactant Producing Plant Growth Promoting Bacteria (PGPB) from Hydrocarbon Contaminated Soils of Upper Assam
}

\author{
Mainu Kalita, Duarah Krondashree, Sosanka Protim Sandilya, Kamal Das, \\ Dutta Kironta, Mahananda Chutia, Ranjana Das and Gangavarapu Subrahmanyam*
}

\author{
Department of Pathology, Central Muga Eri Research and Training Institute (CMER\&TI), \\ Central Silk Board, Ministry of Textiles, Govt. of India, Lahdoigarh-785700, \\ Jorhat, Assam, India \\ *Corresponding author
}

\begin{tabular}{|l|}
\hline K e y w o r d s \\
$\begin{array}{l}\text { Bioremediation, Crude oil } \\
\text { polluted soils, Bacterial } \\
\text { diversity, Biosurfactant } \\
\text { producing bacteria, Plant } \\
\text { growth promoting } \\
\text { bacteria }\end{array}$ \\
\hline Article Info \\
\hline $\begin{array}{l}\text { Accepted: } \\
\text { 04 November } 2018 \\
\text { Available Online: } \\
\text { 10 December } 2018\end{array}$ \\
\hline
\end{tabular}

10 December 2018

\section{A B S T R A C T}

Bioremediation is a highly potential approach to restore and rehabilitate oil polluted soils having many recalcitrant polyaromatic hydrocarbons (PAHs) such as dibenzothiophene (DBT), benzothiophene (BT), etc by use of microorganisms. In the present study biosurfactant producing bacterial diversity and distribution for bioremediation of oil contaminated soils of upper Assam for the growth of Muga host plant Som (Persea bombycina) were studied. Crude oil contaminated soil samples were collected from Lakwa, Gelakey, and Nazira regions of upper Assam and heterotrophic bacteria were isolated. Various screening methods for biosurfactant production as well as plant growth promoting properties were characterized for the bacterial isolates. Results of the drop collapse assay indicated the presence of biosurfactant producing bacteria. Emulsification index (EI) of 40 bacterial isolates revealed that L3, L5, L6, N2, N9, N13, N14, G1, G3, G7, G8, G9, G10, G11 isolates had higher biosurfactant production. EI values of these isolates were significantly high (> 35\%) indicating potentiality higher biosurfactant production. Blue agar CTAB method was done to characterize the presence of anionic biosurfactants. Screening of PGPR activity was checked by starch hydrolysis, phosphate solubilization and extracellular enzyme screening such as catalase, lipase and cellulose. Among all the isolates, N6, N14, G1, G3, G7, G8, G9 showed good plant growth promoting characters along with biosurfactant producing ability. Heterotrophic biosurfactant producing bacterial diversity has been deciphered by 16S rRNA gene sequencing. Results indicated that abundance of Bacillus sp., Pseudomonas sp., Staphylococcus sp., Enterococcus sp., Klebsiella sp. and Serratia sp. in hydrocarbon contaminated soils.

\section{Introduction}

With increase in industrialization, not only air, but soil is also getting contaminated by various toxic pollutants such as sulfur polycyclic aromatic hydrocarbons (PASHs) (released by oil and energy industries which are recalcitrant in nature (Kuppusamy et al., 
2017). This ultimately have a negative impact on soil beneficial microbiota and subsequently reduced agricultural yield including production of sericulture (Ghosal et al., 2016, Prasad et al., 2011; Subrahmanyam et al., 2016; Thavamani et al., 2012). Increased production of industrial waste, traffic pollution, and household garbage has led to migration of many sulfur polycyclic aromatic hydrocarbons (PASHs) and other pollutants into soils through dry and wet atmospheric deposition. PAHs tend to accumulate in the soils as they are sparingly soluble, readily absorbable by soil particles, and difficult to be degraded Tang et al., 2005; Wang et al., 2007). The most important sink for PAHs (polycyclic aromatic hydrocarbons) in the environment are soils.

By physical, chemical, and other biological methods soil which gets accidentally contaminated with petroleum hydrocarbons can be remediated (Bharali et al., 2011). To our knowledge most of the hydrocarbons are biodegradable; nevertheless their rates of biodegradation in the environment are limited due to their hydrophobicity or less accessibility to microbes and low aqueous solubility (Santos et al., 2016). Use of biosurfactant is one of the approaches to enhance biodegradation of crude oil contamination (Cubitto et al., 2004) which could increase the solubility of hydrophobic substrates like oils in aqueous medium and enhances the bioavailability of the hydrophobic substrates leading to higher oil degradation.

Biosurfactants are biological surfactants that are amphiphilic containing both hydrophilic and hydrophobic moieties in nature and are produced by microorganisms. By accumulating at the interface between two immiscible fluids such as oil and water biosurfactants reduce surface and interfacial tensions (Nitsehke and Costa, 2007) and potentially increase their bioavailability for use as carbon and energy sources (Mulligan, 2009). The microorganisms survive in the aqueous phase by producing biosurfactant which effectively adsorb, emulsify and disperse or solubilize the oil or hydrophobic substrate (Satpute et al., 2010). The partially purified biosurfactant is known to exhibit antimicrobial activity by inhibiting the growth of several bacterial and fungal species. The biosurfactants with antimicrobial properties has an enormous potential to combat diseases caused by antibiotics-resistant microbes (Ilori et al., 2008).

The aim of improving nutrients availability for plants by using microorganisms is an important practice and necessary for agriculture (Freitas et al., 2007). Plant growth promoting bacteria (PGPB) are recognized both as efficient soil microbes and biofertilizers to enhance the growth of several crops and control soil borne pathogens. They can affect plant growth by different direct and indirect mechanisms (Heydarian et al., 2016). Various mechanisms that are active due to use of PGPRS are (1) increase in nitrogen fixation and mineral nutrient solubilization (2) repression of pathogens which are soilborne by production of hydrogen cyanide, siderophores, antibiotics, and/or competition for nutrients; (3) improving plant stress tolerance to drought, salinity, and metal toxicity; and (4) production of phytohormones such as indole-3-acetic acid (IAA) and ACC deaminase (Subrahmanyam et al., 2018). Reports are present that suggest significant increase in growth and yield of agronomically important crops in response to inoculation with PGPB. PGPB strains producing rhamnolipids could be a better measure for reclamation of petrol contaminated sites (Youssef et al., 2004).). It is anticipated that indigenous bacteria existing in hydrocarbon contaminated soils areas usually acquire natural resistance against toxic pollutants 
present in their environment. The resistant PGPB ability to promote plant growth in contaminated environment makes them the preferred choice for the bioremediation and sustainable agriculture technologies (Subrahmanyam et al., 2018). Therefore, the present study was aimed to isolate and characterize biosurfactant producing PGPB for enhanced production of Muga silkworm (Antheraea assamensis Helfer) host plants (Persea bombycina) in oil polluted soils of Upper Assam. Mitigating the phytotoxic effects of crude oil in Muga silkworm host plant fields would be beneficial for sustainable sericulture and restoration of soil health.

\section{Materials and Methods}

\section{Soil sampling and Isolation of heterotrophic} bacterial isolates

Hydrocarbon contaminated soil of Muga host plants were collected in triplicates from three regions of Sivsagar district; Lakwa $\left(27.0136^{\circ}\right.$ $\left.\mathrm{N}, 94.8572^{\circ} \mathrm{E}\right)$, Nazira $\left(26.9007^{\circ} \mathrm{N}, 94.7226^{\circ}\right.$ E), Gelakey $\left(26.7959^{\circ} \mathrm{N}, 94.6915^{\circ} \mathrm{E}\right)$ from where isolation of heterotrophic bacterial isolates were done in Luria-Bertani medium $2.5 \mathrm{gl}^{-1}$ supplemented with bacteriological agar $2 \mathrm{gl}^{-1}$ Pure bacterial isolates were obtained from mixed bacterial cultures by streak plate method after an incubation period of 2 days at $30+5^{0} \mathrm{C}$.

\section{Screening for biosurfactant producing bacteria}

\section{Drop collapse test}

Drop collapse assay has been done in order to check the capability of the isolates to produce biosurfactant. A film was xylene was taken on a petriplate where pure broth cultures of bacterial isolates were dropped with the help of a dropper, and water was taken as control (Irorere, 2017).

\section{Emulsification test}

Quantitative estimation for biosurfactant production was done by this method. Several colonies of a pure culture were suspended in test tubes containing $2 \mathrm{ml}$ of LB broth after 48 $\mathrm{h}$ incubation, $2 \mathrm{ml}$ xylene was added to each tube and mixture vortexed at high speed for $1 \mathrm{~min}$, they were leaved to stand for $24 \mathrm{~h}$. The emulsification index is given as percentage of height of emulsified layer $(\mathrm{cm})$ divided by total height of the liquid column $(\mathrm{cm})$ following Saruboo's method (Saravanan and Vijaykumar 2012).

\section{Blue agar CTAB plate assay}

Blue agar CTAB plate assay was done to check the anionic property of the biosurfactant produced by the bacterial isolates. This was done by making wells of about $4 \mathrm{~mm}$ by cork borer at equal distances where bacterial broth was incubated.

The medium used for detection anionic biosurfactants was Bushnell-Hass agar 23.27 $1^{-1}$ supplemented with $2 \%$ glucose, cetyltrimethyl ammonium bromide (CTAB) 0.5 $\mathrm{mgml}^{-1}$, methylene blue 0.2 mgml $^{-1}$. Appearance of a dark blue halo around the spot indicates the anionic property of the biosurfactant (Satpute et al., 2008).

Screening of PGPR activity of different isolates

\section{Phosphate solubilization}

A loop full of fresh bacterial cultures will be streaked on the centre of agar plates modified with Pikovskaya agar with insoluble tricalcium phosphate (TCP) and incubated for $120 \mathrm{~h}$ at $30 \pm 2^{\circ} \mathrm{C}$ (Bhattacharyya and Jha, 2012). The presence of halo zone around the bacterial colonies indicates positive for phosphate solubilization ability. 


\section{Catalase activity}

Bacterial cultures were grown in nutrient agar medium for $48 \mathrm{~h}$ at $32^{\circ} \mathrm{C}$. $48 \mathrm{hr}$ old bacterial colonies were added with 2-3 drops of hydrogen peroxide (3\%) on a clean glass slide and mixed using a sterile tooth pick. The evolution of oxygen as effervescence is an indicative of catalase activity (Joseph et al., 2012).

\section{Lipase activity}

Bacterial isolates were inoculated in nutrient agar medium amended with egg yolk. After 48 hours of incubation plates were flooded with saturated solution of $\mathrm{CuSO}_{4}$ and kept for 15-20 minutes. Greenish blue color zones around the colonies are an indicative of lipase activity (Kumar et al., 2012; Geetha et al., 2014).

\section{Starch hydrolysis test}

Bacterial isolates were inoculated on starch agar plates for a period of 2days incubation at $32^{\circ} \mathrm{C}$. After 2 days plates were flooded with iodine solution for a minute. Clear zone indicates production of extracellular amylase or starch hydrolysis (Geetha et al., 2014).

\section{Biochemical tests}

Biochemical testing of the isolates were done on the basis of the protocol mentioned in KB002 HiAssorted ${ }^{\mathrm{TM}}$ Biochemical Test Kit (for gram-negative), and $\mathrm{KB} 013 \mathrm{HiBacillus}^{\mathrm{TM}}$ Identification Kit (for gram-positive) made of HiMedia Laboratories Pvt. Ltd, Mumbai400086, India. (Email: techhelp@ himedialabs.com.)

\section{Molecular identification of biosurfactant} producing bacterial isolates

Genomic DNA was extracted from $5 \mathrm{ml}$ of each of the grown screened bacterial isolates have following Kate Wilson genomic DNA extraction protocol (Wilson, 2001). The size of the extracted DNA was checked on a $0.8 \%$ agarose gel and the purity of DNA was evaluated by spectrophotometry (NanoDrop Technologies, Wilmington, DE, USA) Subsamples of extracted DNA were kept at $20{ }^{\circ} \mathrm{C}$ for further quantitative and qualitative analysis (Subrahmanyam et al., 2014). Bacterial 16S rRNA genes suitable for diversity profiling were amplified using universal eubacterial primer sets $8 \mathrm{~F}$ (AGAGTTTGATCCTGGCTCAG) and 1492R (GGTTACCTTGTTACGACTT) (Eurofins Genomics, Bangalore, India). The PCR was performed in $50 \mu \mathrm{l}$ volumes containing $25 \mu \mathrm{l}$ of DreamTaq Green PCR Master Mix (2X) (ThermoFisher Scientific, Mumbai, India), $1 \mu \mathrm{l}(0.1-1.0 \mu \mathrm{mol})$ of each primer and $1 \mu \mathrm{l}(10 \mathrm{pg})$ of template DNA. Briefly, a touchdown thermal cycle strategy consisting of 30 cycles $\left(30 \mathrm{~s}\right.$ at $94{ }^{\circ} \mathrm{C}$, annealing for $1 \mathrm{~min}$ at temperature at $55^{\circ} \mathrm{C}$ and extension at $72{ }^{\circ} \mathrm{C}$ for $1 \mathrm{~min}$ then a final extension for $7 \mathrm{~min}$ at $72{ }^{\circ} \mathrm{C}$ were performed in Applied Biosystems Veriti ${ }^{\mathrm{TM}}$ 96-Well Fast Thermal Cycler (ThermoFisher Scientific, Mumbai, India).The PCR products were resolved in $1 \%$ agarose gels, stained with ethidium bromide (5 $\mathrm{ng} \mathrm{ml}-1)$ and analyzed using a gel documentation system (Gel DocTM XR+, BioRad, USA).

\section{S rRNA sequence analysis}

Purified PCR amplicons of the biosurfactant producing bacterial isolates were sent for $16 \mathrm{~S}$ rRNA gene sequencing to Eurofins Genomics, Bangalore, India. The obtained sequences were subjected to BLAST analysis in the NCBI GenBank (www.ncbi.nlm.nih.gov) database, and sequence chromatograms were manually edited with DNAStar and DNAMAN version 6.0. Phylogenetic analysis was conducted using MEGA X. (Kumar et al., 2018) 


\section{NCBI accession numbers}

16S rRNA gene sequences obtained in this study were submitted to NCBI GenBank (www.ncbi.nlm.nih.gov) under the accession numbers MH909822 to MH909836.

\section{Results and Discussion}

A total of 40 pure heterotrophic bacterial colonies were obtained from hydrocarbon contaminated soils of Lakwa, Gelakey, Nazira regions (Sivasagar district) of upper Assam. 10 heterotrophic bacterial isolates were isolated from Lakwa region which were named as L1 to L10; 15 from Nazira, N1 to N15; and 15 from Gelakey, G1 to G15. All the bacterial isolates were screened for biosurfactant producing capacity and PGPR activity.

Screening of biosurfactant production was done by three methods; drop collapse assay, emulsification index and blue CTAB agar method. Drop collapse assay indicated the presence of biosurfactants. Drops of that bacterial culture broth capable of producing biosurfactants on xylene film appeared flat, and spread out with uneven boundaries whereas water drop taken as control appeared more round and intact. Almost all the isolates showed some amount of biosurfactant produced. Therefore a more reliable test i.e. emulsification index was done for quantitative analysis of the biosurfactant produced by the bacterial isolates.

Results of emulsification index method showed that 15 bacterial isolates were capable of producing biosurfactants in good quantity. Isolate number L3, L5, L6, N2, N6, N9, N13, N14, G1, G3, G7, G8, G9, G10, G11 showed quantifiable amount (>35\%) of biosurfactants produced (Fig. 1A, 1B, 1C). Results also showed that isolates obtained from Gelakey region showed a very high amount of biosurfactant produced where the value of emulsification index EI was > 50\% (Fig. 1C). EI value of G1 $58.48 \%$, G3 $55.45 \%$, G7 $54.54 \%$, G8 $61.51 \%$, G9 $62.42 \%$ and these values are comparable to EI values standard bacterial strains reported earlier, for eg. Bacillus subtilis MTCC 2422 showed an EI value of 75\%; Bacillus subtilis MTCC 2423 showed EI value of 78\% (Satpute et al., 2008).

Blue CTAB agar method was done to check the chemical nature of the biosurfactant i.e. whether the biosurfactant produced was anionic or cationic in nature. A dark blue color halo around the bacterial colony indicated anionic nature of biosurfactant produced. Out of the 15 biosurfactant producing isolates only two of them, N2 and N6 produced biosurfactant that were anionic in nature. From the above results it can be inferred that isolate G1, G3, G7, G8, G9 as potential biosurfactant producing bacterial isolates. Since, biosurfactants are biological agents that reduce the interfacial tension between two immiscible liquid; the property of releasing biosurfactants by these bacterial isolates will make enzymes, hormones or chemicals released by these bacteria to be at an accessible state or reach for the Muga host plants Som. Hence, after screening of biosurfactants produced, these bacterial isolates were again screened for PGPR activity and biochemical test.

Different PGPB screening that were done were starch hydrolysis test, catalase test, phosphate solubilising test, and lipase activity (Table 1). Positive starch hydrolysis test showed a clear zone around the bacterial colony as indication of enzyme amylase being produced which is responsible for breakdown of amylase. Isolates N6, N14, G1, G7, G8, G8 and G9 showed positive starch hydrolysis test. Interestingly all the 15 bacterial isolates tested for phosphate solubilisation showed negative results. 
Table.1 Characterization of plant growth promoting activities of biosurfactant producing bacterial isolates obtained from crude oil contaminated soils

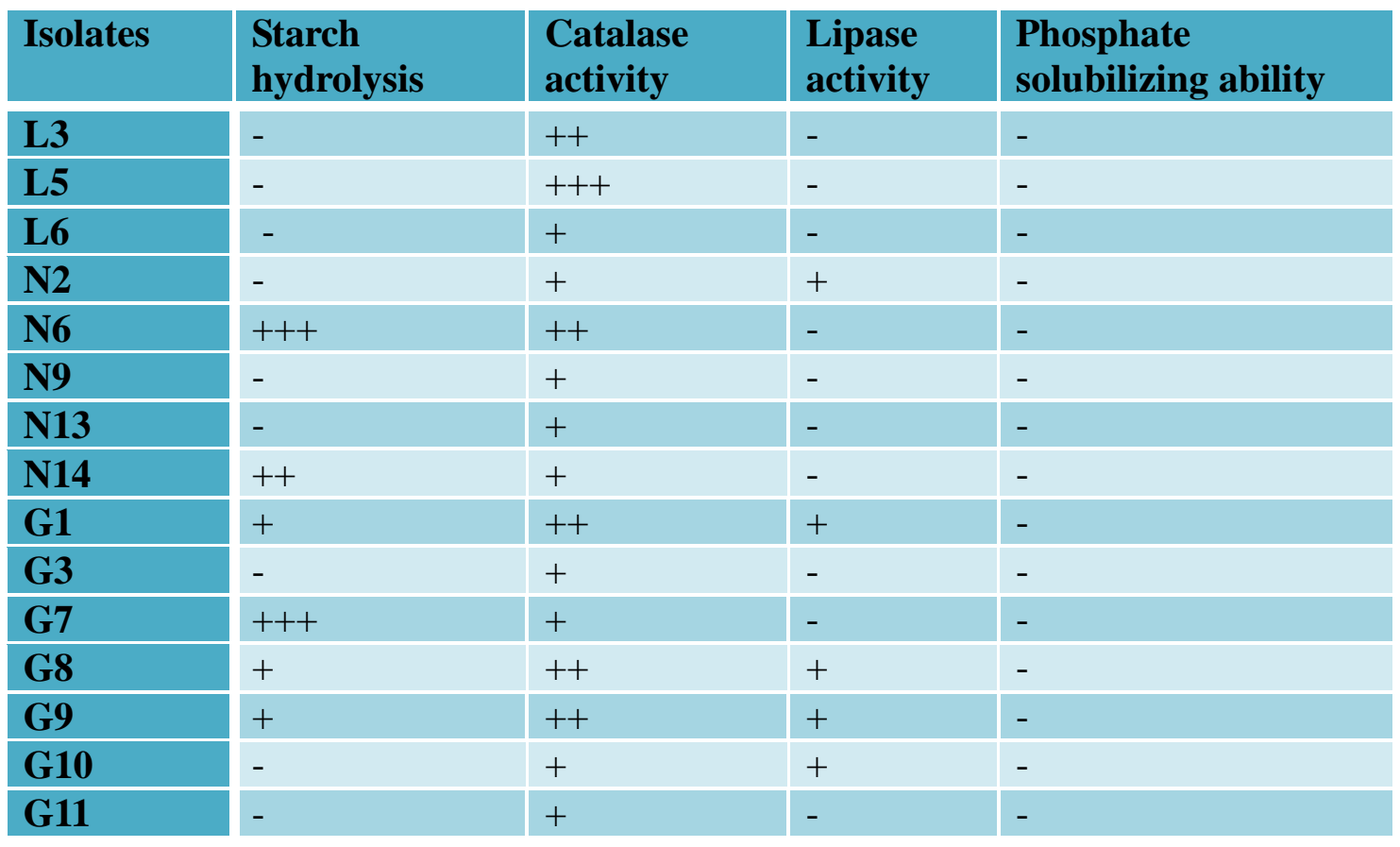

Table.2 Biochemical tests of the biosurfactant producing bacterial isolates (Gram negative) isolated from Lakwa, Nazira and Gelakey region of upper Assam using in KB002 HiAssorted ${ }^{\mathrm{TM}}$ Biochemical Test Kit (HiMedia Laboratories Pvt. Ltd, Mumbai-400086, India)

\begin{tabular}{|c|c|c|c|c|c|c|}
\hline S.no & Tests & G1 & G8 & G9 & N2 & N13 \\
\hline 1 & $\begin{array}{l}\text { Citrate } \\
\text { utilization }\end{array}$ & + & + & + & - & - \\
\hline 2 & $\begin{array}{l}\text { Lysine } \\
\text { utilization }\end{array}$ & + & + & + & - & - \\
\hline 3 & $\begin{array}{l}\text { Ornithine } \\
\text { utilization }\end{array}$ & + & + & + & - & - \\
\hline 4 & Urease & + & + & + & - & - \\
\hline 5 & $\begin{array}{l}\text { Phenylalanine } \\
\text { Deamination }\end{array}$ & + & + & + & - & - \\
\hline 6 & $\begin{array}{l}\text { Nitrate } \\
\text { Reduction }\end{array}$ & - & - & - & - & - \\
\hline 7 & $\mathrm{H} 2 \mathrm{~S}$ production & - & - & - & - & - \\
\hline 8 & Glucose & - & - & - & + & + \\
\hline 9 & Adonitol & - & - & - & + & + \\
\hline 10 & Lactose & - & - & - & + & + \\
\hline 11 & Arabinose & + & + & + & + & + \\
\hline 12 & Sorbitol & - & - & - & + & + \\
\hline
\end{tabular}


Table.3 Biochemical tests of the biosurfactant producing bacterial isolates (gram positive) isolated from Lakwa, Nazira and Gelakey region of upper Assam using KB013 HiBacillus ${ }^{\mathrm{TM}}$ Identification Kit (HiMedia Laboratories Pvt. Ltd, Mumbai-400086, India)

\begin{tabular}{|l|l|l|l|l|l|l|l|l|l|} 
Sl.no & Tests & N6 & N9 & L3 & L5 & L6 & G3 & G7 & G11 \\
\hline $\mathbf{1}$ & Malonate & - & - & - & - & - & + & + & - \\
\hline $\mathbf{2}$ & $\begin{array}{l}\text { Voges } \\
\text { Proskaver }\end{array}$ & - & - & - & - & - & - & - & - \\
\hline $\mathbf{3}$ & Citrate & - & - & - & - & - & + & - & - \\
\hline $\mathbf{4}$ & ONPG & - & - & - & - & - & - & - & - \\
\hline $\mathbf{5}$ & $\begin{array}{l}\text { Nitrate } \\
\text { Reduction }\end{array}$ & + & + & - & - & - & + & + & - \\
\hline $\mathbf{6}$ & Arginine & + & - & - & - & - & - & - & - \\
\hline $\mathbf{7}$ & Sucrose & - & + & + & + & + & + & - & + \\
\hline $\mathbf{8}$ & Mannitol & - & + & - & + & + & - & - & + \\
\hline $\mathbf{9}$ & Glucose & - & + & - & + & + & + & + & + \\
\hline $\mathbf{1 0}$ & Arabinose & + & + & - & + & + & + & - & + \\
\hline $\mathbf{1 1}$ & Trehalose & - & + & - & + & + & + & - & + \\
\hline
\end{tabular}

Fig.1 Emulsification index (EI) of the biosurfactant producing bacterial isolates obtained from (A) Lakwa, (B) Nazira and (C) Gelakey region of upper Assam.

A:

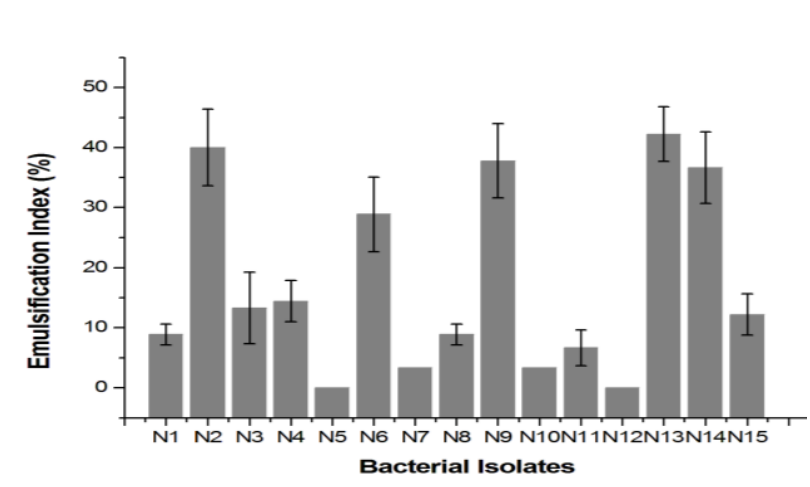

B:

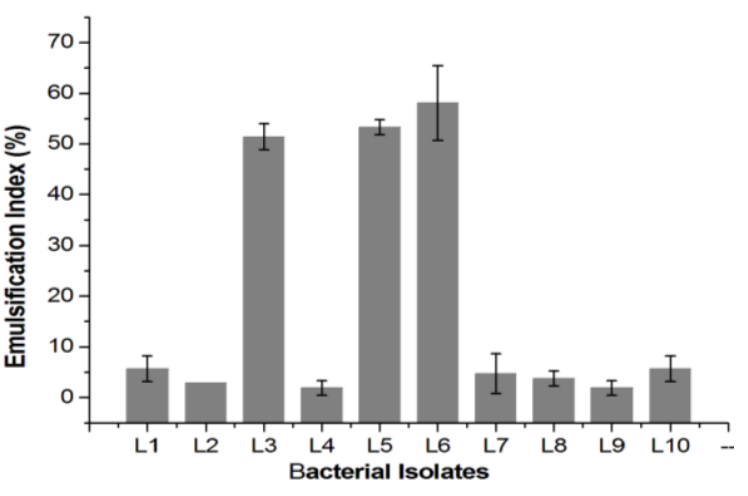

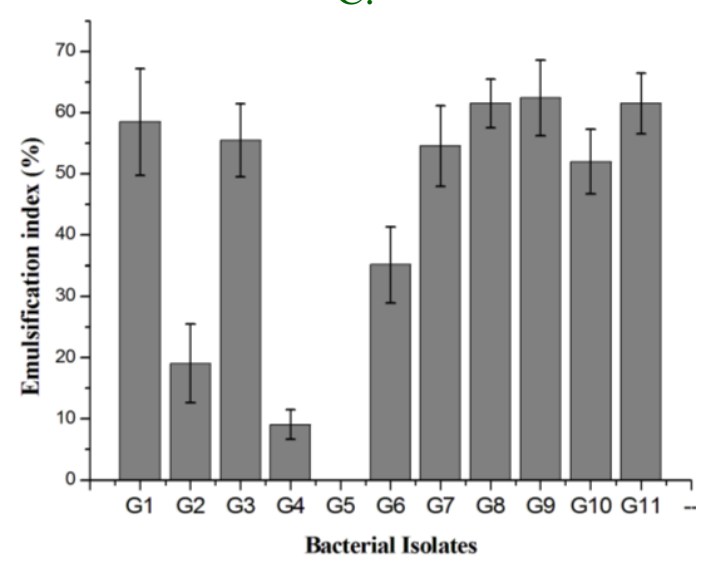


Fig.2 Identification and phylogenetic relation of biosurfactant producing bacterial isolates obtained from crude oil polluted soils. The evolutionary history was inferred by using the Maximum Likelihood method based on the Tamura 3-parameter model. The tree with the highest $\log$ likelihood (-9170.94) is shown. Bootstrap values of trees in which the associated taxa clustered together is shown next to the branch points. Biosurfactant producing bacterial isolates are shown with triangles on phylogenetic tree. NCBI accession numbers for all the isolates are shown in parenthesis

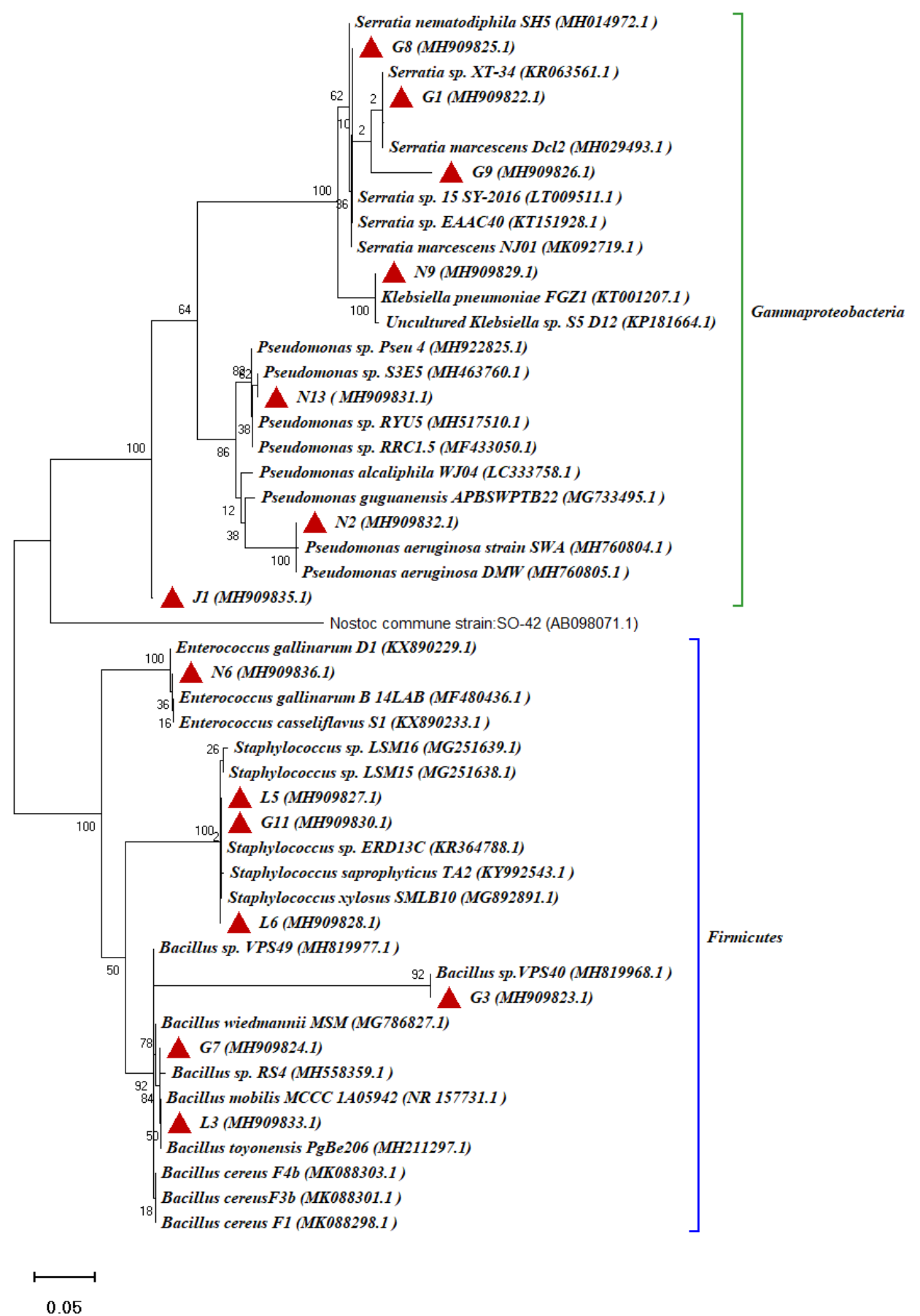


Positive lipase activity showed dark greenish blue color halo around the bacterial isolate indicating the production of the enzyme lipase which is responsible for breakdown of fats. N2, G1, G8, G9 and G10 showed positive results for lipase activity. Catalase activity was checked; production of effervescence indicated positive catalase activity. All 15 bacterial isolates showed positive catalase activity. These results ithat isolate G1, G8, G9 showed good PGPR activity (Table 1)

Biochemical characterization of the all 15 biosurfactant bacterial isolates was also done and it was found that isolate G1, G3, G7, G8, G9 found to show positive results in almost all the tests performed by biochemical test kit (Table 2 and 3 ).

This could be indicative that these bacterial isolates have a potentiality in utilization of wide variety of carbon compounds for their cellular growth. These bacterial isolates shall be used as suitable candidates for remediation of soil pollution as the isolated showed to metabolize diverse carbon sources (Table 2 and 3).

Molecular identification of the biosurfactant producing bacterial isolates were done with 16S rRNA gene amplification and sequencing. Results showed that isolates found were L3 as Bacillus sp., L5 as Staphylococcus sp., L6 as Staphylococcus sp.; N2 as Pseudomonas sp.; N6 as Enterococcus sp.; $\quad \mathrm{N} 9 \quad$ as Klebsiella sp.;N13 as Pseudomonas sp.; G1, as Serratia sp.; G3 as Bacillus sp.; G7 as Bacillus sp.; G8 as Serratia sp.; G9 as Serratia sp.; G11 as Staphylococcus sp. (Fig. 2). The bacterial isolates were identified till genus level and it was found that majority of the bacterial isolates were from the genus Bacillus sp.; Pseudomonas sp., and Serratia sp., Klebsiella $s p$. under phyla Firmicutes and class Gammaproteobacteria (Fig. 2).
The 16S rRNA gene sequences of the bacterial isolates were submitted in NCBI and the accession numbers of the bacterial isolates were obtained (MH909822 to MH909836). These bacteria populations may have a great potential for the bioremediation of toxic chemicals. Indigenous microorganisms as potential bioremediators for environments contaminated with heavy metals were reported in earlier study (Subrahmanyam et al., 2016; Keshri et al., 2014). In the present study abundance of bacteria under phyla "Firmicutes" and class "Gammaproteobacteria" noticed in crude oil polluted soils (Fig. 2). These results are in accordance with previous findings where class Betaproteoabcteria and Gammaproteobacteria were detected in polluted soils (Subrahmanyam et al., 2016; Thavamani et al., 2012). These phyla are frequently observed in soils contaminated with persistent organic pollutants, hydrocarbons and heavy metals in many previous studies (Popp et al., 2006; Thavamani et al., 2012, Vivas et al., 2008). In earlier studies it was found that bacteria from phyla Firmicutes, Actinobacteria and Acidobacteria found to be the abundant lineages pointing their adaptability to pollution stresses. The phylogenetic classification of bacterial isolates obtained from hydrocarbon contaminated soils is consistent with in situ analyses of bacterial community structure in other studies (Subrahmanyam et al., 2016; Keshri et al., 2014).

Serratia sp. G1, Bacillus sp. G7, Serratia sp. G9 and Enterococcus sp. N6 showed good biosurfactant producing capability as well as PGPR activity. Hence, these bacterial isolates could be used to improve soil health which in turn might help muga host plants to grow better in soils contaminated with hydrocarbons. Oil industries have been carrying out oil exploration, production and 
refining activities for decades in upper Assam (Sivsagar District, Dibrugarh District, Golaghat District and Digboi District etc.). In these areas, soils of Muga rearing fields are polluted during oil drilling and refining operations and subsequently pose toxic effect on metabolism and growth of host plants mainly Som, Persea bomsbycina a primary food plant of Muga silkworm, Antheraea assamensis Helfer. In general, bacteria will able to degrade oil pollutants by excreting extra cellular enzymes and thereby increasing soil quality. Thus the bacterial isolated obtained in this study will be explored for improving host plant "Som" growth, production, and palatability of leafs for productivity of Muga culture especially in Muga rearing fields polluted by oil contaminates in upper Assam region.

\section{Acknowledgement}

We are grateful to Department of Science and Technology (DST), Govt. of India. New Delhi for funding this work, under the grant no YSS/2015/001541.

\section{References}

Bharali, P., Das, S., Konwar, B. K. and Thakur A. J. (2011). Crude biosurfactant from thermophilic Alcaligenes faecalis: feasibility in petrospill bioremediation. Int Biodeter Biodegr., 65, 682-690.

Bhattacharyya, P. N. and Jha, D. K. (2012). Plant growth-promoting rhizobacteria (PGPR): emergence in agriculture. World J Microbiol Biotechnol., 28, 1327-1350.

Cubitto, M.A., Moran, A. C., Commendatore, M., Chiarello, M. N., Baldini, M. D. and Sineriz F. (2004). Effects of Bacillus subtilis O9 biosurfactant on the bioremediation of crude oil-polluted soils. Biodegradation., 15, 281-287.
Freitas, A. D. S. D., Vieira, C. L., Santos, C. E. D. R., Stamford, N. P. and Lyra, M. D. C. C. P. (2007). Characterization of isolated rhizobia from Pachyrhyzus erosus L. cultivated in saline soil of the State of Pernambuco, Brazil. Bragantia., 66, 497-504.

Geetha, K, Venkatesham E, Hindumathi A, and Bhadraiah. B. (2014). Isolation, screening and characterization of plant growth promoting bacteria and their effect on Vigna Radita (L.) R. Wilczek. Int J Curr Microbiol Appl Sci., 3, 799899.

Ghosal, D., Ghosh, S., Dutta, T.K. and Ahn, Y. (2016). Current state of knowledge in microbial degradation of polycyclic aromatic hydrocarbons (PAHs): a review. Front Microbiol., 7, 1369.

Heydarian, Z., Yu, M., Gruber, M., Glick, B. R., Zhou R., and Hegedus D. D. (2016). Inoculation of soil with plant growth promoting bacteria producing 1aminocyclopropane-1-carboxylate

deaminase or expression of the corresponding acdS gene in transgenic plants increases salinity tolerance in Camelina sativa. Front Microbiol., 7, 1966.

Ilori, M. O., Adebusoye, S. A. and Ojo, A. C. (2008) Isolation and characterization of hydrocarbon-degrading and biosurfactant-producing yeast strains obtained from a polluted lagoon water. World J Microbiol Biotechnol., 24, 2539-2545.

Irorere, V. U., Tripathi, L., Marchant, R., McClean, S., and Banat, I. M. (2017) Microbial rhamnolipid production: a critical re-evaluation of published data and suggested future publication criteria. Appl Microbiol Biotechnol., 101, 3941-3951.

Joseph, B., Patra, R. R., and Lawrence, R. (2012) Characterization of plant growth promoting rhizobacteria associated with 
chickpea (Cicer arietinum L.). Int $J$ Plant Prod., 1, 141-152.

Keshri, J., Mankazana, B. B. and Momba, M. N. (2014). Profile of bacterial communities in South African minewater samples using Illumina nextgeneration sequencing platform. Appl Microbiol Biotechnol., 99, 3233-3242.

Kumar, A., Kumar, A., Devi, S., Patil, S., Payal, C., and Negi, S. (2012) Isolation, screening and characterization of bacteria from Rhizospheric soils for different plant growth promotion (PGP) activities: an in vitro study. Recent Res Sci Technol., 4 (1).

Kumar, S., Stecher, G., Li, M., Knyaz, C., and Tamura K. (2018). MEGA X: Molecular Evolutionary Genetics Analysis across computing platforms. Molecular Biolo Evol 35:1547-1549.

Kuppusamy, S., Thavamani, P., Venkateswarlu, K., Lee, Y.B., Naidu, R. and Megharaj, M. (2017) Remediation approaches for polycyclic aromatic hydrocarbons (PAHs) contaminated soils: Technological constraints, emerging trends and future directions. Chemosphere., 168, 944-968.

Mulligan, C. N. (2009) Recent advances in the environmental applications of biosurfactants. Curr Opin Colloid Interface Sci., 14, 372-378.

Nitschke M., and Costa S. G. V. A. O. (2007) Biosurfactants in food industry. Trends Food Sci. Technol., 18, 252-259.

Popp, N., Schlömann, M. and Mau, M. (2006). Bacterial diversity in the active stage of a bioremediation system for mineral oil hydrocarbon-contaminated soils. Microbiology, 152, 3291-3304.

Prasad, D., Subrahmanyam, G., and Bolla. (2012) Effect of cadmium on abundance and diversity of free living nitrogen fixing Azotobacter spp. J Environ Sci Technol., 5, 184-191.
Santos, D., Rufino, R., Luna, J., Santos, V., and Sarubbo, L. (2016) Biosurfactants: multifunctional biomolecules of the 21st century. Int J Mol Sci., 17, 401.

Saravanan, V., and Vijayakumar, S. (2012) Isolation and screening of biosurfactant producing microorganisms from oil contaminated soil. J. Acad. Indus. Res., 1, 264-268.

Satpute S. K., Banat I. M., Dhakephalkar P. K., Banpurkar A. K., and Chopade B.A. (2010) Biosurfactants, bioemulsifiers and exopolysaccharides from marine microorganisms. Biotechnol Adv., 28, 436-450.

Satpute, S. K., Bhawsar B. D., Dhakephalkar P. K. and Chopade B. A. (2008). Assessment of different screening methods for selecting biosurfactant producing marine bacteria. Ind $J$ Mar Sci., 243-250.

Subrahmanyam, G., Khonde, N., Maurya, D. M., Chamyal, L. S. and Archana, G. (2014). Microbial activity and culturable bacterial diversity in sediments of the Great Rann of Kachchh, Western India. Pedosphere., 24, 45-55.

Subrahmanyam, G., Sharma, R. K., Kumar, G. N., and Archana, G. (2018). Vigna radiata var. GM4 plant growth enhancement and root colonization by a multi-metal-resistant plant growthpromoting bacterium Enterobacter sp. C1D in $\mathrm{Cr}$ (VI)-Amended Soils. Pedosphere., 28, 144-156.

Subrahmanyam, G., Shen, J. P., Liu, Y. R., Archana, G. and Zhang, L. M. (2016). Effect of long-term industrial waste effluent pollution on soil enzyme activities and bacterial community composition. Environ Monit Assess., $188,112$.

Tang, L., Tang, X. Y., Zhu, Y. G., Zheng, M. H., and Miao Q. L. (2005) Contamination of polycyclic aromatic 
hydrocarbons (PAHs) in urban soils in Beijing, China. Environ Int., 31, 822828.

Thavamani, P., Malik, S., Beer, M., Megharaj, M. and Naidu, R. (2012). Microbial activity and diversity in longterm mixed contaminated soils with respect to polyaromatic hydrocarbons and heavy metals. J Environ Manage., 99, 10-17.

Vivas, A., Moreno, B., del Val, C., Macci, C., Masciandaro, G. and Benitez, E. (2008). Metabolic and bacterial diversity in soils historically contaminated by heavy metals and hydrocarbons. $J$ Environ Monitor, 10, 1287-1296.
Wang, Z., Chen, J., Qiao, X., Yang, P., Tian, F., and Huang, L. (2007) Distribution and sources of polycyclic aromatic hydrocarbons from urban to rural soils: a case study in Dalian, China. Chemosphere., 68, 965-971.

Wilson, K. (2001) Preparation of genomic DNA from bacteria. Curr Protoc Mol Biol., 56, 2-4.

Youssef, N. H., Duncan, K. E., Nagle, D. P., Savage, K. N., Knapp R. M., and McInerney M. J. (2004). Comparison of methods to detect biosurfactant production by diverse microorganisms. J Microbiol Methods., 56, 339-347.

\section{How to cite this article:}

Mainu Kalita, Duarah Krondashree, Sosanka Protim Sandilya, Kamal Das, Dutta Kironta, Mahananda Chutia, Ranjana Das and Gangavarapu Subrahmanyam. 2018. Diversity and Distribution of Biosurfactant Producing Plant Growth Promoting Bacteria (PGPB) from Hydrocarbon Contaminated Soils of Upper Assam. Int.J.Curr.Microbiol.App.Sci. 7(12): 204215. doi: https://doi.org/10.20546/ijcmas.2018.712.026 